\title{
Soil Fauna: A Retrospection with Reference to Indian Soil
}

\author{
Umesh Kumar ${ }^{1}$, Rajendra Singh \\ ${ }^{1}$ S. R. Degree College, Gajpur, Banspar, Gorakhpur \\ Department of Zoology, D.D.U. Gorakhpur University, Gorakhpur, U.P., India \\ rsinghgpu@gmail.com
}

\begin{abstract}
Soil is a living, dynamic ecosystem. Healthy soil is packed with microscopic and larger organisms that perform many vital functions including converting dead and decaying matter as well as minerals to plant nutrients. Different soil organisms feed on different organic substrates. Their biological activity depends on the organic matter supply. Nutrient exchanges between organic matter, water and soil are essential to soil fertility and need to be maintained for sustainable production purposes. Where the soil is exploited for crop production without restoring the organic matter and nutrient contents and maintaining a good structure, the nutrient cycles are broken, soil fertility declines and the balance in the agro-ecosystem is destroyed. Soil organic matter - the product of on-site biological decomposition - affects the chemical and physical properties of the soil and its overall health. Soil ecosystem supports a complex of animal communities of which soil arthropods were of prime importance since they constitute the major component of soil mesofauna in all types of soils. The soil arthropods includes a variety of mites, collembolans, pseudoscorpions, centipedes, millipedes, symphylans, diplurans, proturans, hymenopterans, coleopterans etc. they play an important role in releasing nutrients and improve productivity within the forest ecosystem (less disturbed ecosystem) by decomposition process. Mostly they are present with numerically abundant in the undisturbed, natural forest. Among the soil arthropod Acarina and Collembola are the most diverse as well as abundant group. The present article reviews the research work done in this field with reference to India. A detail account of update distribution of acarines and collembolans (bulk of the soil fauna) and their ecology was given.
\end{abstract}

Keywords: Soil fauna, soil acarines, Collembola, soil ecology, soil fertility.

\section{INTRODUCTION}

The soil is one of the most valuable resources on this planet. From the food we eat, to the clothes we wear, our existence is inextricably linked to the fate of our soils. Soil is a complex and fragile medium, an amalgamation of water, air, minerals and organic matter. About half of the volume of any soil consists of pore spaces containing varying proportions of air and water, while the other half is principally the mineral component, comprised of weathered parent bedrock and deposited minerals. The soil is also a complex living body that breaths, assimilates organic and inorganic elements, breakdowns and mineralizes organic matters of biological origin, and stores reserves as organic matter. In soil, these functions are accomplished by organisms inhabiting through their metabolism. These activities of soil organisms indeed transform and regenerate the soil components. Energy enters in the soil-system mainly through the decomposition of organic matters, whose rate of decomposition is governed mainly by the microbial biomass. Another aspect to consider is the contamination of soil by inorganic elements and/or organic compounds that can significantly change manner the activity of the microbial pool and other indispensable organisms ensuring that soil remains a living ecosystem. Soil is among the most biologically diverse habitat to support wide varieties of living components in the form of flora and fauna on earth. Among the faunal components, there can be representatives of about 20 different lineages of Arthropoda, the most diverse phylum of living organisms. They have been reported to occur in varied soil conditions in different ecosystems. Arthropods in soil encompass a broad range of guilds, including specialised and polyphagous predators, parasites, phytophages, fungivores, microbivores, saprophages, detritivores, and omnivores. Arthropods in soil act as "driving variables" indirectly affecting pathways of energy transfer in soil at levels that are orders of magnitude greater than direct faunal contributions to nutrient and energy fluxes [1]. In addition to the arthropod fauna, other soil organisms ranged from the myriad of invisible microbes, bacteria and fungi to the more familiar macro fauna such as earthworms, beetles, centipedes, termites etc. Plants roots can also be considered as soil organisms in view of their symbiotic relationship and interactions 
with other soil components. These diversed organisms interact with one and other with the various plants and animals in the ecosystem forming a complex web of biological activities. Environmental factors, such as temperature, moisture and acidity as well as anthropogenic actions, in particular management practices, affect soil biological community and their functions to their different extents $[2,3]$.

The interacting functions of soil organisms and the effects of human activities in managing land for agriculture and forestry affect soil health and quality to sustain plant and animal production, maintain or enhance water and air quality and support human health and habitation. The concept of soil health includes the ecological attributes of the soil, which have implications beyond its quality or capacity to produce a particular crop. The soil quality and health are chiefly associated with the soil biota: its diversity, its food web structure, its activity and the range of functions it performs. Therefore, soil biodiversity and abundance may not be a soil property critical for the production, but it is a property that may be vital for the continued capacity of the soil to support the production. In tropical countries like India where population growth is high and soil tends to be highly weathered besides having low fertility, the role of soil fauna becomes very important. This biodiversity in soil organisms, especially the beneficial ones, play an important role in maintaining and improving soil fertility [4].

The activities of macro fauna such as earthworms and termites affect soil structure through mixing soil horizons and organic matter and increases porosity. This directly related to soil erosion and availability of the soil nutrients to plants. The soil meso- and micro- fauna may contribute to decomposition of complex organic matter by breaking the larger plant components into small pieces, thereby increasing their surface area, or even by decomposing the plant biomass directly. Some soil borne pathogens and nematodes may be detrimental to plant growth, for example, the build up of nematodes or disease under certain cropping practices. The activities of certain organisms determine the carbon cycle- the rate of carbon sequestration and gaseous emissions and soil organic matter transformation. Plant roots, through their interactions with other soil components and symbiotic relationships, especially Rhizobium bacteria and Mycorrhiza, play key role in the uptake of nutrients and water, and contribute to the maintenance of soil porosity and organic matter content, through their growth and biomass. Soil organisms can also be used to reduce or eliminate environmental hazards resulting from accumulations of toxic chemicals or other hazardous wastes.

The plant litter decomposition is a key process in global carbon and nutrient cycling $[5,6]$. The litter decay is governed by a number of biotic and abiotic factors and their interactions. The activity of the decomposition processes depends on the soil contents of organic matter, conditions of soil drainage, temperature of the upper soil horizon [7] and soil organisms [8]. Soil fauna have a great influence in functioning of the decomposer flora as a result of their feeding activities [9]. They are the primary agents for the release of nutrients immobilized by the soil microflora [10].

Litter arthropods are mostly members of the detritus based "brown" food web (BFW). BFWs are responsible for the recycling of nutrients and releasing the energy locked in all plant tissues [11-13]. They also constitute half or more of arthropod diversity in a tropical forest [14]. Litter arthropods are assumed to be generalists because leaf litter and litter arthropods do not coevolve [15-17]. Unlike aboveground herbivore assemblages [18], litter arthropods do not interact directly with living plants, but harvest nutrients from dead plant material and the microbes decomposing the litter [19, 20]. Nonetheless, the extent to which litter arthropods in BFWs conform to the TSH remains largely untested [21-26].

\section{SOIL ZOOLOGY IN INDIA: HISTORY}

The research development in soil fauna from Darwin to the current holistic view that tends to link the diversity and functions of aboveground and belowground communities was nicely reviewed earlier [27]. The current knowledge on the role of soil biota, their diversity and various components has accumulated mainly during the last 30 years, resulting in the modern view of soil fauna as a part of the ecosystem [27]. The arthropod fauna of the soil and overlying layer of organic debris normally includes a variety of mites, collembolans, pseudoscorpions, centipedes, millipedes, isopods, proturans, diplurans, symphylans, hymenopterans, coleopterans, and larval forms of many other orders. In most soil and litter worldwide, Acarina (mites) and Collembola (springtail) are the most diverse and abundant arthropods [28]. For the current investigation the soil fauna is used in the group of soil arthropods with special reference to Collembola and Acarina due to their wide distribution in nature 
as well as they are numerically abundance. The two groups are often combined in soil ecological studies as "microarthropods" and other remaining groups designated as "other arthropods". Among arthropods, oribatid mites and collembolans have a great potential as bioindicators of environmental conditions [29, 30], land use intensification [31]. The mites and collembolans constitute 72 to 97 per cent of the total arthropod fauna of Indian soil [32-34]. The importance of feeding of both the macroand microarthropods vary among different ecosystems [35]. It is reported that in the presence of this fauna the mass loss and mineralization of detritus is enhanced by about 23 per cent [19]. However, it is being increasingly felt that there are several gaps in our present knowledge about the regulatory role of these soil fauna in such terrestrial ecosystems.

The study of soil animal has been neglected field for a long time particularly in India but last few decades this study becomes so popular that someone or somebody else from every nook and corner of the world starts working on this field. The vast majority of scientific literature on soil fauna, both taxonomy and ecology, have been mostly from the European and North American soils. Yet soil zoology truly developed as a discrete discipline only during the last 50-60 years. Landmarks in this maturation process included the appearance of Bodenbiologie, produced in an English edition in 1961, summarizing the greater part of what was known about soil animals [36], and Bodenzoologie, in which he emphasized the practical implications of the study of the soil fauna [37].

These works proclaimed a rapid spawning of concurrent literature on soil fauna and international symposia, devoted exclusively to soil animals. Some of these important works included those of [3846]. These authors have drawn together a considerable amount of information on the general Biol. \& Ecol. of soil animals, and have done much to stimulate interest in this field. Also symptomatic of this interest was the creation of international journals of soil Biol. \& Ecol., viz. Pedobiologia in 1961 and Revue D'Ecologie et de Biologic du Sol in 1964.

Systematic survey of literature on Indian soil zoology is difficult as they are distributed in obscure journals. Scanty literature on the subject speaks of its poor attention received from Indian pedologists [47]. Added to this, there is growing evidence of interest from Indian workers as indicated by the proceedings of two national symposia "Soil Biol. \& Ecol. in India" [48], and "Progress in Soil Biol. \& Ecol. in India" [49], followed by "Applied Soil Biol. \& Ecol. " [50] and "Advances in Management and Conservation of Soil Fauna" [51] signaling the gradual maturity of soil faunal studies in India. These publications attempted to bridge the gap in the knowledge on soil Biol. \& Ecol. in this country, which is, as yet insignificant compared to its vast landscape variation and severe pressures on fragile soils. Added to this venture was the launching of the Indian J. Soil Biol. \& Ecol. in 1981.

The earliest taxonomic records of soil fauna from the Indian sub-continent dates back to 1892 [52], reporting upon the ground-dwelling myriapods of the then Ceylon (Sri Lanka) and Southern India. Writing on the then British India, Bingham [53] reported on many of the ground-dwelling ants, while Imms [54] described new collembolan species of this sub-continent.

Qualitative and quantitative studies of soil fauna, particularly the micro-arthropods from Indian soils began from the mid-sixties, although ecological studies were initiated much earlier [55]. However, major contributions have been from the agricultural fields, grasslands, abandoned fields and tea gardens, and very few from tropical rainforests [56-59]. Sanyal [61] has reviewed the ecological studies of soil oribatid mites in India. Later on, the tropical forest soil and litter microarthropods were studied [32, 62]. Most of the recent literatures on Indian soil fauna are again from the agricultural fields.

The rapid accumulation of literature on soil fauna during this period was also due to simultaneous availability of improved soil fauna sampling techniques [63-65] and though most were improvements and modifications of Tullgren's apparatus. [66],

Fragmentary knowledge of the soil fauna of northeast India is through the limited reports concentrating on the arthropod populations of the pine forest floors [67-79]; soil fauna of jhum fallows at lower elevations [80-81]; differences in the arthropod structure in the forests and jhum fallows and other cultivated fields of this region [82-89] and the microarthropods of rubber cultivations in Tripura [90].

Other workers like reported on the ecological study of soil microarthropods in different ecosystems of India including the detail biodiversity study of soil fauna subsequent to slash and burn agriculture or shifting cultivation in north-east India. [34, 60-62, 67, 91-95]. 


\subsection{Soil Fauna of Acarines (Subclass : Acari)}

Following is the taxonomy of subclass Acari (Class : Arachnida, Subphylum : Chelicerata, Phylum : Arthropoda) that includes soil fauna:

Subclass : Acari

Superorder : Acariformes

Order : Sarcoptiformes

Suborder : Acaridei (= Astigmatina, soil mites )

Suborder : Oribatida (= Cryptostigmata, soil mites)

Order: Trombidiformes

Suborder : Prostigmata (soil mites)

Suborder : Sphaerolichida (2 Superfamilies)

Superorder : Parasitiformes

Order : Holothyrida (small group feeding dead arthropods)

Order : Ixodida (ticks, animal ectoparasites)

Order : Mesostigmata (ca. 100 families, mostly soil mites)

Order : Opilioacarida (only 1 family, rare)

Acari is one of the major subclass of Arachnida and is divided into 2 superorders : Acariformes and Parasitiformes. Acariformes includes orders, viz. Astigmatina, Orbatida and Prostigmata that live in soil.

\subsubsection{Oribatida (= Cryptostigmata)}

The biodiversity of soil oribatid mites was studied in different parts of the country, for example, in Maharshtra [96-100]; Himachal Pradesh [101, 102], Tripura [86, 103-112], Meghalaya [61], West Bengal $[99,100,113]$. Bhaduri and Raychaudhuri [114] accounted the taxonomy and distribution of oribatid mites of India.

Oribatid mites have five active postembryonic instars, all of which feed on a wide variety of material including living and dead plant and fungal material, lichens and carrion, some are predaceous, none is parasitic, and feeding habits may differ between immatures and adults of the same species [115-117]. Generally oribatid mites have low metabolic rates, slow development and low fecundity and exemplify "k-selected" organisms [118]. Norton [119] reported that the adults are living from several months to 2 years in temperate forest soils. Many oribatid species sequester calcium and other minerals in their thickened cuticle. There are reviews on the role of Oribatida in decomposition and nutrient cycling [19, 120], and their role as bioindicators in agriculture [30, 121-127].

\subsubsection{Mesostigmata}

The Mesostigmata are numerically dominant predators in soil and litter [128-134]. They are more active and respond more sensitivity over shorter periods of time to environmental influences in soil ecosystems than many other soil arthropods [132, 135-137]. Mostly they are free living and represent the largest suborder of the parasitiforms. They primarily feed on nematodes, collembolans, and other soft-bodied mites and small insects in agricultural soils [138-139]. Many have more than one prey group and some are omnivores; feeding on fungi and animal prey [140]. Many species have high metabolism, high fecundity and short life spans; some completed their life cycle withiin 4-7 days. They can, therefore, respond very rapidly to increased prey in the habitat. Usually mesostigmata are heavily sclerotized with colours that tend towards brown or shades and parasitic forms may be colourless. The role of as bioindicators had been described in detail [136, 141-142].

\subsubsection{Prostigmata}

The member of Prostigmata are large, extremely diverse group of mites. They are mostly soft bodied, with adults varying in size from $100 \mu \mathrm{m}$ to $10 \mathrm{~mm}$. The composition of prostgmatid communities at the family level is tough to be similar over a number of different habitats [143-145]. The species can be 
algivorous, bacterivorous, fungal feeders, phytophagous, predators, parasites and parasitoids. Many species have high metabolism, high fecundity, and short life spans; some complete their life cycle in about a week. These suborders are cosmopolitan in distribution and are truly unlimited in habitat. They can therefore, respond very rapidly to nutrient pulses in the environment [146].

\subsubsection{Acaridei ( = Astigmata)}

The members of Acaridei are free living and commonly known as cheese mites having no stigmata and trachea. They feed on plant material, fungi and algae, preferably of high protein content and also consume the liquefied products of decaying organic material [147]. Astigmata have higher fecundity, faster development and much higher reproductive rates than other oribatid mites [119]. Many species can complete their life-cycle in 8 days to 3 weeks depending on relative humidity and temperature [148]. Under laboratory conditions females can lay up to 800 eggs in a month [147]. This fecundity, combined with rapid development and an effective phoretic stage, means that Astigmata can respond rapidly to nutrient availability.

Among the four suborders of mites, Cryptostigmata always dominated others followed by Mesostigmata, Prostigmata and Astigmata except some habitats [32, 61, 67, 87, 149-153]. In prairie also Cryptostigmata can be among the most diverse mite suborder [154]. Cryptostigmata occur in greatest numbers in coniferous forest soil where they may represented as much as 75 percent of the total acarine fauna [155]. Oribatid mites are the dominant component of the microarthropod fauna in most forest floor systems [156], and thus contribute in increasing decomposition and maintaining fertility and structure of the soil. About $95 \%$ of the total density of Cryptostigmata occurred in the $0-4$ $\mathrm{cm}$ soil layer [157]. Studies on the interrelation of mite population with the physical factors of soil like temperature, moisture content, relative humidity, $\mathrm{pH}$, rainfall etc. showed to exert significant or insignificant positive correlations with the mite population.

\subsection{Soil Fauna of Collembola}

The Collembola (springtails) are the most abundant entognathous, wingless insects in the soil throughout the world, found in vast numbers from the tropics to the poles. They are abundant in the soil and their density can reach $98 \%$ proportion of the total density of Arhtropoda collected. There are about 8600 described species of Collembola worldwide [158]. Indian fauna of Collembola represents 299 species in 103 genera under 18 families [159]. They are less than $6 \mathrm{~mm}$ in length. The collembolans have very diverse distribution occurring in all Zoogeographical regions of the world inhabiting a wide range of ecological niche and climate. It includes a variety of habitats where they feed as scavengers on decaying vegetation and soil fungi even occurring in the vicinity of both south and north poles. The collembolans are major components of terrestrial ecosystems and particularly significant members of the soil communities, constituting a significant proportion of the animal biomass reaching densities of 200 to 1800 individuals per $\mathrm{cm}^{3}$, densities surpassed by the Acarine soil population [160]. Mandal and Hazra [161] nicely compiled and reviewed the diversity and ecology of Collembola from East and North-East India. They reported a total 76 species of Collembola belonging to 38 genera and 6 subfamilies obtained from the soil and leaf-litter of the above mentioned states of India. Amongst them, 28 species were endemic to the said regions i.e. $36.84 \%$ total species recorded of these states and $14.28 \%$ of total Indian fauna of collembolan. Richest diversity of Collembolan fauna was found in the state of Sikkim which includes 39 species under 26 genera, where as minimum diversity was observed in the state of Meghalaya with 11 species under 5 genera. Lal et al. [162] investigated the population dynamics of Collembola in wetlands and croplands in Indo-Gangetic plains of north Bihar and Mandal et al. [163] studied on diversity and distribution of Collembola in the man made forest ecosystem in West Bengal and nicely reviewed the earlier work on this group citing several recent past references. Singh and Kumar [164] observed the ecology of soil arthropods including Collembola in both protected and degraded sal and teak forest ecosystem of Gorakhpur, Uttar Pradesh

\subsection{Other Soil Fauna}

Other soil fauna includes proturans, diplurans, ants, mole crickets, pests associated with mulch and moisture, soil-dwelling beetles and grubs, spiders, subterranean termites, millipedes, centipedes, symphylans, earthworms etc. These invertebrates build holorganic structures (their faecal pellets) that serve as incubators for microbial activities; some time after deposition, they reingest these pellets to assimilate metabolites that have been released by the microflora [165-166]. The earthworms and 
social insects (ants and termites) are able to efficiently dig the soil and produce organo-mineral structures and a large variety of pores. The size of these organisms allows the development of anisosymbiotic relationships with microflora in their proper gut, which is likely to be much more efficient than the external relationships in faecal pellets. Termites accelerate tremendously the mineralisation of litter through their internal and external (fungus gardens) digestive processes, but then accumulate the remaining carbon and nutrients by aggregating their pellets into the highly compact structure of the termitaria where virtually no mineralisation occurs until the colony dies [167]. In India, soil macrofauna had been studied in some detail [168-171].

\section{Role OF Soil Fauna in SoIl Fertility}

Soil represents one of the most important reservoirs of biodiversity. It reflects ecosystem metabolism since all the bio-geo-chemical processes of the different ecosystem components are combined within it; therefore soil quality fluctuations are considered to be a suitable criterion for evaluating the longterm sustainability of ecosystems [172]. Within the complex structure of soil, biotic and abiotic components interact closely in controlling the organic degradation of matter and the nutrient recycling processes. Soil fauna is an important reservoir of biodiversity and plays an essential role in several soil ecosystem functions; furthermore, it is often used to provide soil quality indicators. Although biodiversity was one of the focal points of the Rio conference, in the 1990s virtually no attention was paid to activities for the conservation of soil communities. However, with the new millennium, the conservation of soil biodiversity has become an important aim in international environmental policies [172].

Studies on the role of soil fauna in ecosystem functioning require accurate characterization of the soil community food web, identifying the potentially important species and groups as well as the interactions among them [173]. Proper understanding on the contribution of different faunal groups to the ecosystem process are required for developing environmentally sound management practices and strategies to safeguard the biodiversity and soil fertility. It has been proposed that a varied and abundant fauna maintains and even enhances soil fertility and thus high productivity [174]. Most of the information in this context from India and elsewhere is from natural systems where nutrient cycle is tight and there is no major biomass removal from this site [19, 175-182]. The greatest effect of such microarthropods fauna is reported in forest ecosystem with well developed litter layers $[4,183]$ and grassland ecosystems [184-185]. A few studies have also been conducted to determine the role of soil micro and meso fauna in agro forestry/silvipasture systems and in crop/fodder production systems [186-190].

\subsection{Ecological Study of Soil Fauna}

Krebs [191] indicated an important aspect of ecological study of soil microarthropod in describing and understanding the pattern of distribution in its habitat. A natural habitat such as soil in undisturbed forest ecosystem provides a diverse group of arthropod fauna. In undisturbed soil, interactions among animals and between animals and microarthropods form an integrated system for the decomposition of organic matter and recycling of mineral nutrients $[19,192]$. The animals in the soil participate in numerous processes of soil formation and affect the usefulness of soils. The classical role of the soil fauna is in the breakdown of dead plants and animals, which are returned to the soil. Accompanying this decaying process is the release of nutrients from the organic body of plants and animals into the soil. Effects of animals in and on soil result in changes in soil fabrics, i.e., size, shape, arrangement of soil components and changes in soil composition. There are at least twelve kinds of activities by which soil animals affect the soil [193]. These activities include mounding, mixing, forming voids, back-filling voids, forming and destroying peds, regulating soil erosion, regulating movement of water and air in soil, regulating plant litter, regulating animal litter, regulating nutrient cycling, regulating biota, and producing special constituents through the processes of regurgitation, mixing of saliva or excreta with soil materials. Soil arthropod biodiversity is an indicator of soil quality. The biomass of fauna is a relatively small proportion of the total soil mass, particularly in a mineral soil, yet the activity of these animals is important in moving material upward against the forces of gravity and of the flow of fluids, in altering soil fabric and micro-topography, in changing distribution patterns of soil materials and plant nutrients and in relating processes and assemblages of materials and organisms. 
An understanding of the importance of these organisms to soil ecology is still in its infancy, microarthropods may play a significant role in accelerating plant residue decomposition through their interactions with the microflora [19-20, 29, 31, 194-196]. The flow of energy and nutrients through the soil may be accelerated by microarthropods [34, 176-181]. Yet in order to predict the consequences of human mediated impacts on forest soil systems, it is crucial to gain a better understanding of the functional role soil organisms play in maintaining the integrity and health of the soil ecosystem (188-189, 197-199].

The species composition and abundance of the soil fauna are influenced by the geographical location climate, physical and chemical properties of the soil, type of vegetation cover, nature and depth of the litter and humus and a variety of other environmental factors. Moreover, soil animals are directly associated with the soil structure through fecal deposition and drilling of pores [200] and commonly show a non-random distribution with small localized pockets of high density [201]. Thus the fauna of the soil may vary considerably from one locality to another.

\subsubsection{Ecology of Soil Acari}

Acarina (mites) are often the dominant group of arthropods in the forest floors and trees. $[119,202-$ 204]. Mites are the rival of insects in the diversity of living habits and niches occupied [205] and are inhabitants of all kinds of soil, from extremely acid to alkaline, and from nutrient poor to nutrient rich and have been found up to $10 \mathrm{~m}$ deep in soil [146]. Like other arachnids, mites possess six pairs of articulated appendages: two pair of mouthparts (chelicerae and pedipalps) and four pairs of legs. Larvae have only three pairs of legs. The chelicerae are contained in a through or tube like structure formed by parts of the pedipalps. This so-called gnathosoma is a distinct part of the mite body and is characteristic for the order Acarina [206]. Soil and litter are the ancestral homes of Acarina and these are still the habitats from which their greatest diversities and abundances have been reported. There can be up to 250 different mite species and 8,00,000 individuals in a square metre of the organic layer of forest soil [207]. Still, investigations of mite diversity have largely been limited to the litter and the top part of the hemiorganic horizon [22].

Acarina include predators, parasites, parasitoids, fungal feeders, root feeders dead plant feeders, algal feeders, bacterial feeders, omnivores, and scavengers. Acarina have a diversity of functions in the ecosystem, as evidenced by the range of the feeding guilds to which they belong and they can catalyzed primary decomposition and nutrients cycling in soil [208], activating fungi and bacteria [20]. Acarines are essential for efficient decomposition and nutrient cycling [19]. They also performed other ecosystem functions which include biological control, suppression of soil borne diseases and pests, dispersal and vectoring of helminth parasites, and sequestering of carbon and other minerals [209].

Prostigmata and Oribatida are associated with different organic matter cycles [2010]; prostigmatids with the fast cycle and oribatids with the slow cycle. The abundance and diversity of Oribatida clearly reflected resource stability, presence of a litter layer and lack of habitat disturbance [154]. Most of the oribatid mites are restricted to the upper soil layer where they live in decaying leaf litter for the purpose of decomposers of plant debris. These detritivore arthropods on leaf-litter could enhance the rate of mobilization and enrichment of nutrients in the environment readily available for the uptake by plants roots [211]. Cryptostigmatid mites are very sensitive to temperature changes [212, 213].

\subsubsection{Ecology of Soil Collembola}

The Collembola (springtail) are small apterygote insects and cosmopolitan in distribution. They are common, numerically dominant and species rich among the fauna of soils supporting temperate and tropical grassland, moorland, heathland and forests throughout the world. Most soil forms range in size from 0.5 to $3.0 \mathrm{~mm}$ and feed on decaying vegetation and/or microbes.

Collembola have two life forms, i.e. epedaphic and euedaphic. The ededaphic Collembola are those which are present in ground and leaf litter and strikingly large as compared with euedaphic Collembola. Their body has richly pigmented pattern and often bears a dense covering of hairs of scales and possess a long, well-developed furca. The majority of the Entomobryidae and Siminthuridae are representatives of the epedaphic life forms. The euedaphic species inhibits the lower soil layers. Most of them are elongated and cylindrical body form and legs and antennae are reduced. Their furca is frequently non-functional and in some form completely disappeared. Most of 
them are unpigmented and hairless. Onychiuridae are typical representatives of the euedaphic life. However in the present study euedaphic life forms are more common group.

Collembola are active in decomposition; nutrient cycling and soil formation and can affect fungal composition and activity. They have a similar size range to oribatid mites, but their role in ecosystem possesses differs, as they are primarily "r-selected" fungivores and detrivores [166, 214, 215]. As a result collembolan species can respond more rapidly than oribatid mites to ecosystem disturbance $[216,218]$.

Collembolan communities have been related to various habitat factors, such as soil water condition [219, 220], vegetation and soil fertility [221], soil chemistry [222], tree age [223] and other organisms [224]. Further soil moisture strongly influences the distribution and abundance of Collembola [225228].

The organic matter on a forest floor has both quantitative and qualitative importance for Collembola [229]. Abiotic factors, mainly temperature and water content, directly affect activity, fecundity and mortality of Collembola [230]. Soil $\mathrm{pH}$ has been identified as a factor strongly influencing collembolan communities [231-233]. Ponge [234] defined $\mathrm{pH} 5$ as a threshold value separating acidtolerant from acid intolerant collembolan species.

Generally maximum population density of Collembola is observed in the upper soil layer, where the maximum decomposition activity takes place $[91,192,235,236]$. In most permanent grassland, moorland and woodland sites, the collembolan are richly represented in terms of numbers of individuals and species in the organic layer, i.e., in $10-15 \mathrm{~cm}$ soil layer $[230,237]$. Each organic horizon in the forest soil profile present its own distinct complex of environmental features and has its own particular association of animal species. Although seasonal movements up and down the profile do occur in some cases, the center of the population density of many species remains in particular horizons throughout the year. The heterogeneity of organic profile and the diversity of microhabitats occurring in the soil encourages a spatial separation of species populations and reduce inter specific competition and increase species diversity.

\subsubsection{Effect of Climatic Factors on Soil Ecology}

Soil systems are heterogenous and adjacent microhabitats may possess various physical, chemical and biological properties [229]. These various biotic and a biotic factors of soil have influence on the distribution of soil animal. The biotic components of soil such as source of food and vegetation cover are the important factors which impacts on the population of soil fauna. The soil fauna depend on microorganisms like bacteria, fungi, algae, etc. for their food material. The physical and chemical abiotic factors are important in determining the population distribution pattern and species composition of soil microarthopods in the soil ecosystems. The physical factors affecting the soil which form part of the environment of soil arthropod include soil structure, soil moisture, porosity, soil temperature and humidity of soil etc. Among the physical abiotic factors soil moisture takes vital roles in the distribution, abundance and various activities of many soil organisms of their environment. The soil moisture content is of vital importance to the soil fauna [238]. Vertical distribution of soil fauna is mainly influenced by soil moisture [239, 240]. Wallwork [45] also considered, within a climatic region, the main factors determining the abundance of soil microarthropods include: (1) type and quantity of decomposing organic residues and their effects on the micro floral population, (2) structural stability of the soil and resulting porosity, and (3) soil water regime.

Soil varies from place to place depending upon the percentage contribution of the sand, silt and clay. Sandy soils are light and warm and pore spaces are large. These soils are well drained, aerated and loose in texture. The clay soils are heavy, wet and badly drained. Soil structure determines soil porosity. The soil porosity decrease progressively with depth and it is parallel by a succession of species in which larger size of soil animals are confined to the surface layer of the profile, while smaller groups present at the lower levels. The various abiotic chemical substances play important roles in the life cycle of soil arthropods. These abiotic factors include organic carbon, $\mathrm{pH}$, nitrogen and phosphorus and their relationship with the soil fauna have been studied by several workers [241245]. However, among these chemical factors, soil organic carbon is the major constituent of organic matter and it takes better role in determining the character of the soil. High status of organic matter is maintained in the soils by the fall of huge amount of litter on the soil surface and its rapid 
decomposition due to favorable conditions like moisture and temperature [246]. Thus, decomposition represents an ecological service for the whole ecosystem, as $60-90 \%$ of terrestrial primary production is decomposed in the soil [247]. Moreover, the organic carbon content of the soil is an important factor in determining the composition of soil fauna [248]. Soil rich in organic matter are generally rich in nutrients. Organic matter decomposition in soil is performed by a dynamic system of microflora and invertebrate fauna and their synergistic interactions play a very important role in enhancing the nutrient release [211]. Soil pH seemed to have little influence on the distribution of soil arthropods though most of the Collembola and mites prefer slightly acidic soil.

The microclimatic feature provides one of the most attractive features of the habitat as its fauna is concerned. Generally, higher species richness may be expected in a heterogeneous and varying environment than in a homogenous and stable one [249]. Geiger [250] proposed that the fluctuations in temperature and moisture are much less severe than they are at, and above the ground surface and the amplitude of these fluctuations decreases with depth in the soil. Species occur only in relatively dry soil, some in very wet soils, although the majority of the soil fauna evidently prefer conditions that are neither too dry nor too wet.

Collembola and Prostigmata shows a tendency to increase in the drier part whereas the Cryptostigmata and Mesostigmata are relatively abundant in the wetter parts of the soil [45]. Moisture content of the soil was considered to be the most important single responsible microarthropod inhibiting in the soil [251]. Some oribatid were reported to possess a close association with most habitats and hence serve as indicator of humid conditions. A positive correlation exists between microhabitat diversity and Oribatid species diversity in forest soil [252]. Moreover the moisture content of the soil was always dependent on the rainfall received by the soil surface.

Both Collembola [226] and Acari [253] show movement patters within soil profiles in response to unfavourable conditions of relative humidity. The vertical population structure of soil arthropod was little affected by moisture. In forest soil, some species (hemiedaphic) tend to dwell near the soil surface and others (euedaphic) deeper in humus even in the homogeneous substrate and under constant conditions [249]. Cryptostigmata were mostly surface dwellers in litter mats and prostigmata were found in deep layers due to their predatory habit. Acarina as a whole were observed to migrate to deeper soil layer during hot dry and winter season. Mitchell [254] also studied vertical and horizontal distribution of oribatid mites in an Aspen Woodland soil.

\subsubsection{Biodiversity of Soil Biota}

Biodiversity represents the sum total of various life forms such as unicellular micro-organisms and multicellular organisms such as plants, fishes and mammals at various biological levels including gene species, habitats and of ecosystems. In terrestrial systems, the soil is considered a major reservoir of biodiversity [021] and hence, provides a good context for studying the determinants of species richness. Biodiversity of soil arthropods include Acari or mites, Collembola or springtail, Coleoptera, centipedes, Diplura, Hymenoptera, millipedes, Protura, pseudoscorpions, Symphyla, and larval forms of many other orders. Among these soil arthropods Acari and Collembola were the most numerically dominant and therefore, in the present investigation more emphasis is given to the Acari and Collembola.

The biotic community of the soil has been considered as peculiar and difficult to explain from current ecological theory in the sense that it often contains thousands of animal species within geographically restricted areas. It is often not apparent that a sufficient number of different niches exist that can cope with the high species richness. Anderson [255] phrased the term "The enigma of soil species diversity" as a title of a paper. Soil arthropod constitutes a major share of the biotic components of the soil. Thus a great variety of organisms exist in the soil and in litter. Some of them are temporary soil inhabitants while others are permanent and some live under surface debris or in soil opening whereas others are burrowing forms. They are directly or indirectly important in decomposition processes and nutrient dynamics of forest ecosystem [11, 118]. Much of the biodiversity of forest ecosystems resides in the soil [256] and the importance of the biodiversity of the soil biota to the integrity and functioning of terrestrial ecosystems, is well recognized [257-259]. There are several reports on the study of arthropods diversity for different ecosystem such as from Himalayan grass land [60], pineforest [69], semiarid Savanna [260] to deciduous forest [261]. 
After the Rio Conference in 1992, biodiversity became synonymous with protecting the environment. Bioindication has emerged as useful process for environmental evaluation particularly of the soil, which is a complex entity able to perform a multitude of key functions, vital for life, such as breathing, assimilating nutrients like carbon and nitrogen, transforming and mineralizing organic materials like vegetables and animals, storing substances in reserve in the form of humus. Direct or indirect contamination of the soil, by inorganic elements and/or organic compounds, can significantly change the activity and the composition of the organisms living in soil (soil biodiversity) and irreversibly prevent the soil fulfilling its key functions to support the planet's ecosystems. For example, decline in organic matter content is closely linked to the loss of soil biodiversity. Recognising that soils contain as much biodiversity as the above ground habitats is the catalyst needed to protect this precious resource from further degradation [262].

It has been suggested that an important step in bioindicator identification studies is to select, in the area to be investigated, potentially less disturbed sites as a 'natural' reference [142, 263, 264]. The uncultivated areas adjacent to cultivated plots are poorly researched, and this confounds our ability to predict changes in soil arthropod populations following cultivation [121]. As a result, we need to obtain preliminary information on the fauna of soil arthropods in natural soils, and use these as reference sites in soil degradation studies. The reasons why we care about soil fauna are related to their intrinsic, utilitarian and functional values [265].

\section{Conclusion}

Soil is a living, dynamic ecosystem. Healthy soil is packed with microscopic and larger organisms that perform many vital functions including converting dead and decaying matter as well as minerals to plant nutrients. Different soil organisms feed on different organic substrates. Their biological activity depends on the organic matter supply. Nutrient exchanges between organic matter, water and soil are essential to soil fertility and need to be maintained for sustainable production purposes. Where the soil is exploited for crop production without restoring the organic matter and nutrient contents and maintaining a good structure, the nutrient cycles are broken, soil fertility declines and the balance in the agro-ecosystem is destroyed. Soil organic matter - the product of on-site biological decomposition - affects the chemical and physical properties of the soil and its overall health. Its composition and breakdown rate affect: the soil structure and porosity; the water infiltration rate and moisture holding capacity of soils; the diversity and biological activity of soil organisms; and plant nutrient availability.

Soil ecosystem supports a complex of animal communities of which soil arthropods were of prime importance since they constitute the major component of soil mesofauna in all types of soils. The soil arthropods includes a variety of mites, collembolans, pseudoscorpions, centipedes, millipedes, symphylans, diplurans, proturans, hymenopterans, coleopterans etc. they play an important role in releasing nutrients and improve productivity within the forest ecosystem (less disturbed ecosystem) by decomposition process. Mostly they are presenting with numerically abundant in the undisturbed, natural forest. Among the soil arthropod Acarina and Collembola are the most diverse as well as abundant group. Ecological investigation of soil arthropods helps in understanding, describing and studying the distributional pattern of these animals and also major role in soil formation, nutrient cycling etc. For understanding the importance of soil animals, information on the distribution, abundance as well as interaction with various abiotic factors is also necessary.

\section{REFERENCES}

[1] Anderson J.M., Invertebrate-mediated transport processes in soil, Agric. Ecosyst. Environ. 24, 519 (1988).

[2] Frampton, G.K., Brink, P.J. vanden, den Brink P.J.van, van den, Brink, P.J. and Rusek, J., Influence of cropping on the species composition of epigeic Collembola in arable fields. In: Apterygota at the beginning of the third Millenium. X International Colloquium on Apterygota, Ceske Budejovice, 21-24 August 2000, Pedobiologia 46 (3-4), 328-337 (2002).

[3] Siira-Pietikäinen A., Pietikäinen J., Fritze H. and Haimi J., Short-term responses of soil decomposer communities to forest management, clear felling versus alternative forest harvesting methods, Can. J. For. Res. 31, 88-99 (2001).

[4] Warren M.W. and Zou X.M., Soil macrofauna and litter nutrients in three tropical tress plantations on a disturbed site in Puerto Rico, Forest Ecol. and Manag. 170(1-3), 161-171 (2002). 
[5] Bradford M.A., Tordoff G.G., Eggers T., Jones T.H. and Newington, J.E., Microbiota, fauna, and mesh size interactions in litter decomposition, Oikos 99 (2), 317-323 (2002).

[6] Shaw M.R. and Harte J., Control of litter decomposition in a subalpine meadow sagebrush ecotone under climate change, Ecol. Appl. 11, 1206-1223 (2001).

[7] Striganova B.R., Bienkowski P. and Ben K.P., Rates of decomposition processes in mountain soil of the Sudeten as a function of edaphic-climatic and biotic factors, Izv. Ackad. Nauk Ser. Biol. 6, 734-743 (2000).

[8] Swift M.J., Heal O.W. and Anderson J.M., Decomposition in terrestrial ecosystem. Blackwell Scientific Publ. Oxford, pp. 372 (1979).

[9] Santos P.F. and Whitfortd W.G., The effect of microarthropods on litter decomposition in Chihuahuan desert ecosystem. Ecology 62, 654-663 (1981).

[10] Cortet J., Joffre R., Elmholt S. and Krogh P.H., Increasing species and trophic diversity of mesofauna affects fungal biomass, mesofauna community structure and organic matter decomposition processes, Biol. and Fert. Soils 37(5), 302-312 (2003).

[11] Coleman D.C., Crossley D.A. Jr. and Hendrix P.F., Fundamentals of Soil Ecology, 2nd edn. Elsevier, Oxford, pp. 386 (2004).

[12] Bardgett R.D. The Biology of Soil: a Community and Ecosystem Approach. Oxford University Press, Oxford, pp. 254 (2005).

[13] Bardgett R.D., Usher M.B. and Hopkins D.W., Biological diversity and function in soils. Ecological reviews. Cambridge University Press, Cambridge, pp. 100-118 (2005).

[14] Stork N.E. and Grimbacher P.S., Beetle assemblages from an Australian tropical rainforest show that the canopy and the ground strata contribute equally to biodiversity, Proc. R. Soc. London (B) 273, 1969-1975 (2006).

[15] Scheu S. and Setälä, H., Multitrophic interactions in decomposer communities. In: Multitrophic Level Interactions (Eds. Tscharntke, T. and Hawkins, B.A.). Cambridge University Press, Cambridge, pp. 223-264 (2002).

[16] Wardle D.A., How plant communities influence decomposer communities. In: Biological Diversity and Function in Soils (Eds. Bardgett R.D., Usher M.B. and Hopkins D.W.), pp. 119138 (2005).

[17] Ayres E., Dromph K.M. and Bardgett R.D., Do plant species encourage soil biota that specialise in the rapid decomposition of their litter? Soil Biol. \& Biochem. 38,183-186 (2006).

[18] Coley P.D. and Barone J.A., Herbivory and plant defenses in tropical forests, Annu. Rev. Ecol. \& Syst. 27, 305-335 (1996).

[19] Seastedt T.R., The role of microarthropods in decomposition and miner- alization processes, Annu. Rev. Ent. 29, 25-46 (1984).

[20] Moore J.C., Walter D.E. and Hunt H.W., Arthropod regulating of micro- and meso- biota in below-ground detrital food webs, Annu. Rev. Ent. 33, 419-439 (1988).

[21] Andre H.M., Noti M.I. and Lebrun P., The soil fauna: the other fast biotic frontier, Biodiv. \& Conserv. 3, 45-56 (1994).

[22] Andre H.M., Ducarme X. and Lebrun P., Soil biodiversity: myth, reality or conning, Oikos 96, 324 (2002).

[23] Yanoviak S. and Kaspari M., Community structure and the habitat templet ants in the tropical forest canopy and litter, Oikos 89, 259-266 (2000).

[24] St. John M.G., Wall D.H. and Behan-Pelletier, V., Does plant species co-occurrence influence soil mite diversity? Ecology 87, 625-633 (2006).

[25] St. John M.G., Wall D.H. and Hunt H.W., Are soil mite assemblages structured by the identity of native and invasive alien grasses? Ecology 87, 1314-1324 (2006).

[26] Maraun M., Schatz H. and Scheu S., Awesome or ordinary? Global diversity patterns of oribatid mites, Ecography 30(2), 209-216 (2007).

[27] Huhta V., The role of soil fauna in ecosystems: a historical review, Pedobiologia 50(6), 489-495 (2007).

[28] Foth H.D., Fundamentals of Soil Science ( $7^{\text {th }}$ edition), John Wiley and Sons, pp. 435 (1984). 
[29] Migliorini M., Pigino G., Caruso T., Fanciulli P.P., Leonzio C. and Bernini F., Soil communities (Acari Oribatida: Hexapoda Collembola) in a clay pigeon shooting range, Pedobiologia 49 (1), 113 (2005).

[30] Bispo A., Cluzeau D., Creamer R., Dombos M., Graefe I.U., Krogh P.H., Sousa J.P., Peres G., Rutgers M., Winding A. and Rombke J., Indicators for monitoring soil biodiversity, Int. Envir. Assess. \& Manag. 5, 717-719 (2009).

[31] Ponge J.F., Gillet S., Dubs F., Fedoroff E., Haese L., Sousa J.P. and Lavelle P., Collembolan communities as bioindicators of land use intensification, Soil Biol. \& Biochem. 35(6), 813-826 (2003).

[32] Prabhoo N.R., Soil microarthropods of virgin forest and adjoining tea fields in the Western Ghats in Kerala, Orient. Ins. 10, 435-442 (1976).

[33] Singh J. and Pillai K.S., A study of micro arthropods communities in some fields, Rev. d'Ecol. \& Biol. Sol. 12, 579-90 (1975).

[34] Tripathi G., Kumari R. and Sharma B.M., Association of soil mesofauna with litter decomposition, Cient. Jabot. 33(2), 148-151 (2005).

[35] Petersen H., A review of collembolan ecology in ecosystem context, Acta Zool. Fenn. 195, 111118 (1994).

[36] Kuhnelt W., Soil Biology. Faber, and Faber London, pp. 397 (1961).

[37] Franz H., Bodenzoologie als Grundlage der Bodenpflege, Akademie-Verlag, Berlin, pp. 316 (1950).

[38] Kevan D.K.McE, Soil Zoology, Butterworths Scientific Publications, London, pp. 512 (1955).

[39] Kevan D.K.McE., Soil Animals, Philosophical Library, New York. pp. 237 (1962).

[40] Farb P., Living Earth, Haper and Brothers, New York, pp. 178 (1959).

[41] Macfadyen A., Animal Ecology: Aims and Methods, Pitman, London, pp. 264 (1957).

[42] Doeksen J. and Drift J. van der, Soil Organisms, North-Holland Publishing Co., Amsterdam, pp. 453 (1963).

[43] Burges A. and Raw F., Soil Biology, Academic Press, London, pp. 532 (1967).

[44] Graff O. and Satchell J.E., Progress in Soil Biology, North-Holland Publishing Co., Amstermdam, pp. 656 (1967).

[45] Wallwork J.A., The Distribution and Diversity of Soil Fauna, Academic Press, London, pp. 355 (1976).

[46] Lebrun P., Andre H.M., De Medts A., Gregoire-Wibo C. and Wauthy G. New Trends in Soil Biology, Proc. VIII Int. Coll. Soil Zool., Louvain-la-Neuve, Belgium, pp. 709 (1983).

[47] Singh J., Soil fauna studies in India. In: Soil Biol. \& Ecol. in India (Ed. Edwards C.A. and Veeresh G.K.), UAS Technical Series No. 22, Bangalore, pp. 226-235 (1978).

[48] Edwards C.A. and Veeresh G.K., Soil Biol. \& Ecol. in India. University of Agricultural Sciences, Technical Series No. 22, Bangalore, pp. 344 (1978).

[49] Veeresh G.K. Progress in Soil Biol. \& Ecol. in India, UAS Technical Series No. 37, Bangalore, pp. 340 (1981).

[50] Veeresh G.K. and Rajagopai D., Applied Soil Biol. \& Ecol., Sharda Publishers, Bangalore, pp. 340 (1983).

[51] Veeresh G.K., Rajagopai D. and Viraktamath C.K., Advances in Management and Conservation of Soil Fauna, Oxford and IBH Publishing Col. Pvt. Ltd., New Delhi, pp. 952 (1991).

[52] Pocock R.I., Report upon two collections of Myriapoda sent from Ceylon by Mr. Green and from various parts of Southern India by Mr. Edgar Thurston of the Government Central Museum, Madras, J. Bombay Nat. Hist. Soc. 7, 131-174 (1892).

[53] Bingham C.T., Fauna of British India including Ceylon and Burma: Hymenoptera Vol. 2, Taylor and Francis, London, pp. 534 (1903).

[54] Imms A.D., On some Collembola from India, Burma and Ceylon, Proc. Zool. Soc. London, 80124 (1912).

[55] Trehan K.N., Some observations of the soil fauna of cotton fields at Lyallpur, Proc. Indian Acad. Sci. 21, 191-201 (1945). 
[56] Banerjee S., Microarthropods and humus formation, J. Indian Soc. Soil Sci. 20, 403-405 (1972).

[57] Annadurai R.S., Chandrasekhar S.S. and Balu A., Trophic structure and diversity in some litter inhabiting micro-arthropods of monoculture and natural forest ecosystems, Proc. Indian Acad. Sci. 97, 301-308 (1988).

[58] Reddy J.R. and Reddy M.V., Structure of micro-arthropod communities associated with four types of leaf litters, J. Soil Biol. Ecol. 16, 151-154 (1996).

[59] Bisht B.S and Chattoraj A.N., Distribution of collembolan species at different altitudes and depths in Afaknanda valley of Garhwal Himalayas, Him. J. Environ. \& Zool. 12, 49-53 (1998).

[60] ingh J. and Singh U.R., An ecological study of soil micro-arthropod from soil and litter of tropical deciduous forest of Varanasi (India), Trop. Ecol. 16, 81-85 (1975).

[61] Sanyal A.K., Kundu B.G. and Roy S., Ecology of Soil oribatid Mites (Acari) in relation to some edaphic factors in Gangetic Delta of West Bengal, Rec. Zool. Surv. India, Occas. paper No.177, pp. 1-55 (1999).

[62] Hazra A.K., Soil and litter arthropod fauna of Silent Valley, Kerala: a preliminary report, J. Soil Biol. \& Ecol. 2, 73-77 (1982).

[63] Macfadyen A., Notes on methods for the extraction of small soil arthropods, J. Anim. Ecol. 22, 65-77 (1953).

[64] Macfadyen A., A comparison of methods for extracting soil arthropods. In : Soil Zoology (Ed. Kevan D.K.McE.), Butterworths, London, pp. 315-332 (1955).

[65] Macfadyen, A., Metabolism of soil invertebrates in relation to soil fertility. Ann. Appl. Bio. 49, 216-219 (1961).

[66] Alexander F.E.S. and Jackson R.M., Preparation of sections for study of soil micro-organisms. In: Soil Zoology (Ed. Kevan D.K.McE.), Butterworths, London, pp. 433-440 (1955).

[67] Bhattacharya T. and Joy S., Astudy of the soil microarthropod community of four contrasting soils in Santiniketan (WB), J. Res.Vishwa Bharati Sci. 3, 17-28 (1978).

[68] Reddy M.V., Ecosystem structure of a pine forest in Northeast India with particular reference to consumer and decomposer arthropods, Ph.D. thesis, NEHU, Shillong (1980).

[69] Reddy M.V., Microarthropods and rate of litter disappearance in a pine plantation ecosystem North-Eastern India, Pedobiologia 22, 339-344 (1981).

[70] Reddy M.V. and Alfred J.R.B., Microarthropods associated in the decomposition process of pine litter of Meghataya pine (Pinus kesiya Royle) forests. In: Soil Biology and Ecology in India (Eds. C.A. Edwards and G.K. Veeresh), UAS Technical Series No. 22, Bangalore, pp. 31-35 (1978).

[71] Reddy M.V. and Alfred J.R.B., Some observations on the earthworm population and the biomass in a sub-tropical pine forest. In: Soil Biology and Ecology in India (Eds. C.A. Edwards and G.K. Veeresh), UAS Technical Series No. 22, Bangalore, pp. 78-82 (1978).

[72] Hattar S.J.S. and Alfred J.R.B., A population study and community analysis of Collembola in pine forest soils of Meghalaya, N.E. India, Orient. Ent., Symp. Assoc. Adv. Ent., Univ. Kerala, India, pp. 203-209 (1984).

[73] Hattar S.J.S. and Alfred J.R.B., A population study and community analysis of Collembola in pine forest soils of Meghalaya, N.E. India, Proc. IIIrd Orient. Ent. Symp. Trivendrum, pp. 203209 (1986).

[74] Singh T.B., Yadava P.S. and Singh E.J., Population density of soil arthropods in the subtropical forest ecosystem at Shiroy Hill Manipur, Proc. Symp. Pestic. Res. \& Environ. Poll., pp. 272-288 (1986).

[75] Paul D. and Alfred J.R.B., A comparative study of soil microarthropods in three disturbed habitats of Meghalaya, North-East India, Orient. Ent. Symp. Assoc. Adv. Ent., University of Kerala, India, pp. 221-227 (1984).

[76] Paul D. and Alfred J.R.B., A comparative study of soil microarthropods in three disturbed habitats of Meghalaya, North, East India, Proc. III Orient Ent. Symp. Trivandrum 1, 221-227 (1986).

[77] Paul D. and Alfred J.R.B., Soil arthropod fauna of three agroecosystems as compared to that of undisturbed forests of Meghaiaya, N.E. India, J. Soil Biol. \& Ecol. 15, 52-65 (1995). 
[78] Chitrapati C., Ecological study of soil micro-arthropods in the sub-tropical forest ecosystem at Khonghampat, Manipur, Ph.D. Thesis, Manipur University, Imphal, India (2002).

[79] Mema W., Ecological study of soil and litter microarthropods in the sub-tropical forest ecosystem at Phayeng, Manipur, Ph.D Thesis, Manipur University, Imphal, India (2004).

[80] Vatsauliya P.K. and Alfred J.R.B., Quantitative study of the soil arthropods in Jhum ecosystems of northeast India, Indian Zool. 4,153-160 (1980).

[81] Vatsauliya P.K., Ecological Studies on Jhum Fallows of Byrnihat (Meghalaya) with particular reference to Soil fauna. Ph.D. Thesis, NEHU, Shillong. (1981).

[82] Darlong V.T. and Alfred J.R.B., Differences in arthropod population structure in soils of forest and Jhum sites of Northeast India, Pedobiologia 23, 112-119 (1982).

[83] Darlong V.T. and Alfred J.R.B., Population dynamics of Isotoma (Desoria) trispinata a Collembolan species dominant in pine forest and Jhum soils of Meghalaya. Orient. Ent. Symp., Assoc. Adv. Ent., University of Kerala, India. pp. 211-219 (1986).

[84] Darlong V.T. and Alfred J.R.B., Micro-arthropod diversity in some soils of Northeast with special reference to effect of shifting cultivation. Himalayan Biodiversity Conservation Strategies (Ed. U. Dhar), Gyanodaya Prakashan, Nainital, pp. 311-323 (1989).

[85] Alfred J.R.B., Darlong V.T., Hattar J.S. and Paul D., Microarthropods and their conservation in some north-east Indian soils. In: Advances in Management and Conservation of Soil Fauna (Ed. Veeresh, G.K.). Oxford and IBH Publishing Pvt. Ltd, New Delhi, pp. 309-320 (1991).

[86] Sarkar S., Taxonomy of oribatid mites from the soils of Tripura. I. Two new species of Allonothrus and Eremulus. In: Advances in Management and Conservation of Soil Fauna (Ed. G.K. Veeresh, D. Rajagopal and C.A. Viraktamath), Oxford and IBH Publishing Co. Pvt. Ltd., New Delhi, pp. 727-731 (1991).

[87] Hattar S.J.S., Alfred J.R.B. and Dartong V.T., Soil acarina and collembola in forest and cultivated land of Khasi Hills, Meghalaya, Rec. Zool. Surv. India 92, 89-97 (1992).

[88] Hattar S.J.S., Darlong V.T. and Alfred J.R.B., Animal diversity in some managed and protected forests of North-East India with particular reference to soil fauna. In: Biodiversity Conservation in Managed Forests and Protected Areas (Ed by P.C. Kotwal and S. Banerjee), Agro Botanica, Bikaner, pp. 108-118 (1998).

[89] Reddy M.V. and Ao M.A., Species composition and seasonably in soil surfacearthropod population in two upland agro-ecosystems of Nagaland. In: Advances in Ecology and Environment (Eds. P.C. Mishra, N. Behera, B.K. Senapati and B.C. Guru), Ashish Publishing House, New Delhi, pp. 561-597 (1995).

[90] Chakraborti P. and Bhatacharya T., Fluctuations of soil microarthropos in a rubber plantation and an adjacent wasteland, J. Soil Biol. \& Ecol. 16, 54-59 (1996).

[91] Takeda H., Ecological studies of collembolan population in a pine forest soil II. Vertical distribution of Collembola, Pedobiologia 18, 22-23 (1978).

[92] Sengupta D. and Sanyal A.K., Distribution of soil Acari in South Bihar, with special reference to Cryptostigmata and Mesostigmata. A preliminary report, J. Acarol. 11(1-2), 59-66 (1989).

[93] Haq M.A. and Ramani N., Population ecology of microarthropods in relation to vegetation and rainfall. In: Advances in Management and conservation of soil Fauna (Eds. G.K. Veeresh, D. Rajagopal and C.A. Viraktamath). Proc. $10^{\text {th }}$ Int. Soil Zool. Colloq. Bangalore, pp. 797-803 (1991).

[94] Hattar S.J.S., Darlong V.T. and Alfred J.R.B., Soil fauna diversity and shifting cultivation: an observation from north-east India, Ann. For. 16(2), 340-357 (2008).

[95] Sanyal A.K., Oribatid mites (Acari : Cryptostigmata), Fauna of Meghalaya, Part 2, ZSI, Calcutta, pp. 51-92 (1995).

[96] Hazra A.K., Ecology of Collembola in a deciduous forest floor of Birbhum District, West Bengal in relation to soil moisture, Orient. Ins. 12, 265-274 (1978).

[97] Acharya S. and Basu P., Sixteen new records of soil oribatid mites (Acari: Oribatida) from Maharashtra, India, Biol. Forum - an Internat. J. 6(2), 1-6 (2014).

[98] Acharya S. and Basu P., On a collection of soil oribatid mites (Acari: Oribatida) from Sinhagarh Fort, Pune, Maharashtra, Bionotes 16(2), 71 (2014). 
[99] Acharya S. and Basu P., Oribatid Mite (Acari: Oribatida) fauna of Konkan, Maharashtra, India with new distributional records, Biol. Forum - an Internat. J. 6(2), 77-81 (2014).

[100] Acharya S. and Basu P., Studies on the soil oribatid mite (Acari: Oribatida), fauna of western Vidarbha, Maharashtra, India, IJRSB 3(7), 22-28 (2015).

[101] Banerjee (Moitra) S., Sanyal A.K. and Moitra M.N., Abundance and group diversity of soil mite population in relation to four edaphic factors at Chintamani Abhayaranya, Narendrapur, South 24-Parganas, West Bengal. Proc. Zool. Soc. 62, 57 (2009). doi:10.1007/s12595-009-0008-2.

[102] Acharya S. and Basu P., New records of soil oribatid mites (Acari: Oribatida) from Himachal Pradesh, India: nine genera and thirteen species, J. Exp. Zool. India 17(1), 91-96 (2014).

[103] Sengupta D. and Sanyal A.K., Oribatid (Acari: Oribatei) fauna of the Himalayan soils of Himachal Pradesh, India, Env. \& Ecol. 8(1),149-153 (1990).

[104] Cancela da Fonseca J.P. and Sarkar S., On the evaluation of spatial diversity of soil microarthropod communities, Eur. J. Soil Biol. 32, 131-140 (1996).

[105] Cancela da Fonseca J.P. and Sarkar S., Soil microarthropods in two different managed ecological systems (Tripura, India), Appl. Soil Ecol. 9, 105-107 (1998).

[106] Sanyal, A.K., Diversity in soil oribatid (Acari) mites of Tripura, Rec. Zool. Surv. India 101 (Part 3-4), 55-60 (2003).

[107] Sarkar S., New representatives of oribatid mites (Acari: Oribatei) from soil of Tripura, India, Orient. Zool. 3, 91-98 (1983).

[108] Sarkar S., A new species of the genus Archegozetes Grandjean, 1931 (Acari: Oribatei) from Tripura, India. U. P. J. Zool. 5, 82-85 (1985).

[109] Sarkar S., Notes on zoogeographic affinity of the oribatid mites of Tripura, India, Orient. Ent. Symp., Assoc. for Adv. Ent., University of Kerala, India, pp. 49-54 (1986).

[110] Sarkar S., Studies on microarthropod community in one undisturbed habitat of Tripura (India) with special reference to oribatid mites, Rev. Ecol. Biol. Sol. 27, 307-329 (1990).

[111] Sarkar S., Three new species of the genus Microzetes (Acarina Oribatida Microzetidae) from the soil of Tripura. New record of the genus Schizozetes in India, Bull. Life Sci. 2, 31-39 (1992).

[112] Sarkar S. and Subias L.S., New Lohmannids (Acarida: Oribatida) from India, Orient. Ins. 18, 2530 (1984).

[113] Subias L.S. and Sarkar S., Three new species of Ptyctimines Oribates (Acari) from India (Mesoplophoridae and Phthiracridae), Fol. Ent. Hung. 1, 215-220 (1984).

[114] Moitra M.N., On variation of diversity of soil oribatids (Acari, Oribatida) in three differently used soil habitats- a waste disposal site, a natural forest and a tea garden in the northern plains of Bengal, India, Internat. J. Sci. \& Res. Publ. 3(11), 1-12 (2013).

[115] Bhaduri A.K. and Raychaudhuri D.N., Taxonomy and distribution of Oribatid mites (Acari) in India, Ins. Mats. (N.S.) 23, 21-39 (1980).

[116] Siepel H., Niche relationships between two panphytophagous soil mites, Nohrus silvestris, Nicolet (Acari, Oribatida, Nothridae) and Platynothrus peltifer (Koch) (Acari, Oribatida, Camisiidae), Biol. Fert. Soil 9, 139-144 (1990).

[117] Behan-Pelletier V.M., Acari and Collembola biodiversity in Canadian agricultural soils, Can. J. Soil Sci. 83, 279-288 (2003).

[118] Wakelin S.A., Chu G., Broos K., Clarke K.R., Liang Y. and McLaughlin M.J., Structural and functional response of soil microbiota to addition of plant substrate are moderated by soil $\mathrm{Cu}$ levels, Biol. \& Fert. Soil. 46(4), 333-342 (2010).

[119] Crossely Jr. D.A., The role of terrestrial saprophagous arthropods in forest soils: current status of the concepts. In: The Role of Arthropods in Forest Ecosystem (Ed. Mattson W.J.), Springer, Berlin, Germany, pp. 49-56 (1977).

[120] Norton R.A., Evolutionary aspects of Oribatid mite life histories and consequences for the origin of the Astigmata. In: Mites Ecological and Evolutionary Analysis of Life History Patterns (Ed. Houck, M.A.), Chapman and Hall, London, pp. 99-135 (1994).

[121] Norton R.A., Aspects of the biology of soil and systematic of soil arachnids particularly saprophagous and mycophagous mites, Quaest. Ent. 21, 523-541 (1986). 
[122] Behan-Pelletier V.M., Oribatid mite biodiversity in agroecosystems: roles as bioindicators. Agric. Ecosys. \& Env. 74, 411-423 (1999).

[123] Lindberg N. and Bengtsson J., Population responses of oribatid mites and collembolans after drought, Appl. Soil Ecol. 28(2), 163-174 (2005).

[124] Gulvik M., Mites (Acari) as indicators of soil biodiversity and land use monitoring: a review, Pol. J. Eco. 55(3), 415-440 (2007).

[125] Gergocs V. and Hufnagel L., Application of oribatid mites as indicators (Review), Appl. Ecol. \& Env. Res. 7, 79-98 (2009).

[126] Ivan O. and Vasiliu A., Oribatid mites (Acari, Oribatida) - bioindicators of forest soils pollution with heavy metals and fluorine, Ann. For. Res. 52, 11-18 (2009).

[127] Khalil M.A., Janssens T.K.S., Berg M.P. and Van Straalen N.M., Identification of metalresponsive oribatid mites in a comparative survey of polluted sites, Pedobiologia 52, 207-221 (2009).

[128] Andrievskii V.S., Barsukov P.A. and Bashkin V.N., Application of soil oribatid mites as bioindicators in impact areas of the gas industry in the west siberian tundra, The Open Ecol. J. 8, 32-39 (2015).

[129] Salmane I., Soil free-living predatory Gamasina mites (Acari, Mesostigmata) from the coastal meadows of Riga Gulf, Latvia, Lat. Ent. 37, 104-114 (2000).

[130] Salmane I., The soil-dwelling predatory Gamasina (Acari, Mesostigmata) fauna of seashore habitats on the Kurzeme Coast of Latvia, Ekol. Bratislava 19, 87-96 (2000).

[131] Salmane I., Investigations of the seasonal dynamics of Gamasina mites (Acari, Mesostigmata) in the pine forests of Latvia. Ekol. Bratislava 19, 245-252 (2000).

[132] Salmane I. and Kontschán, J., Soil gamasina mites (Acari, Parasitiformes, Mesostigmata) from Hungary. I, Lat. Ent. 42, 48-56 (2005).

[133] Ruf A. and Beck L., The use of predatory soil mites in ecological soil classification and assessment concepts, with perspectives for oribatid mites, Ecotoxicol. \& Env. Safety 62, 290-299 (2005).

[134] Plowman K.P., Distribution of Cryptostigmata and Mesostigmata (Acari) within the litter and soil layers of two subtropical forests, Aust. Ecol. 6(4), 365-374 (2006).

[135] Gwiazdowicz D.J., Ascid mites (Acari, Mesostigmata) from selected forest ecosystems and microhabitats in Poland, Wyd. Akad. Rolnic. Aug. Cieszk. Poznan, (2007).

[136] Salmane I. and Brumelis G., Species list and habitat preference of Mesostigmata mites (Acari, Parasitiformes) in Latvia, Acarologia 50(3), 373-394 (2010).

[137] Koehler H.H., Predatory mites (Gamasina, Mesostigmata), Agric. Ecosys. \& Env. 74, 395-410 (1999).

[138] Coja T. and Bruckner A., Soil microhabitat diversity of a temperate Norway spruce (Picea abies) forest does not influence the community composition of gamasid mites (Gamasida, Acari), Eur. J. Soil Biol. 39(2), 79-84 (2003).

[139] Karg W., Milben als indikatoren zur optimicrung von pflazenschut-zamssnahmen in apfelintensivanlagen, Pedobiologia 18, 415-425 (1978).

[140] Walter D.E., Hunt H.W. and Elliott T.E., Guilds of functional groups? An analysis of predatory arthropods from a short grass steppe soil, Pedobiologia 31, 247-260 (1988).

[141] Walter D.E. and Lindquist E.E., Life history and behaviour of mites in the genus Lasioseius (Acari: Mesostigmata: Ascidae) from grassland soils in Colorado, with taxonomic notes and description of a new species, Can. J. Zool. 67, 2797-2813 (1989).

[142] Karg W. and Freier B., Parasitiforme raubmilben als Indikatoren fur den Oekologischen zustand von Oekosystemen, Mitt. Biol. Bund. Land. Forst. Berlin-Dahlem. Heft, 305, pp. 96 (1995).

[143] Paoletti M.G., Invertebrate Biodiversity as Bioindicators of Sustainable Landscapes. Practical use of Invertebrates to assess sustainable Landuse, Elsevier, pp. 446 (1999).

[144] Luxton M., Studies on the oribatid mites of a Danish beechwood soil. III. Introduction to the field populations, Pedobiologia 21, 301-311 (1981).

[145] Luxton M., Studies on the astigmatic mites of a Danish beechwood soil, Pedobiologia 22, 29-38 (1981). 
[146] Luxton M., Studies on the oribatid mites of a Danish beechwood soil. VI. Seasonal population changes, Pedobiologia 21, 387-409 (1981).

[147] Kethley J.B., Acarina: Prostigmata (Actinedida). In: Soil Biology Guide (Ed. D.L. Dindal). Wiley Interscience, New York. N.Y., pp. 667-756 (1990).

[148] Philips J.R., Acarina: Astigmata (Acaridida). In: Soil Biology Guide (Ed. D.L. Dindal). Wiley and Sons, New York. N.Y., pp. 757-778 (1990).

[149] Hughes A.M., The mites of stored food and houses, Ministry of agriculture, fisheries and food, technical Bulletin 9, Her Majesty's Stationary Office, London, UK., pp. 400 (1976).

[150] Singh J. and Mukharji S.P., Qualitative composition of soil arthropods in some fields at Varanasi (India), Orient. Ins. 5(4), 487-494 (1971).

[151] Banerjee S., Distribution of Acari in relation to soil conditions in 24-parganas, West Bengal, India. In: Progress in Acarology (Eds. G.P. Channa Basavanna and C. Viraktamath), Vol. I. pp. 451-457 (1988).

[152] Choudhuri D.K. and Banerjee S., Qualitative and quantitative composition of Acari and Collembola in relation to soil organic matter microbes complex, Orient. Ins. 9(3), 313-316 (1975).

[153] Bhattacharya T., Climate, soil and soil inhabiting arthropods of Shantiniketan and adjoining areas, J. Res. Visva-Bharati 3(2), 12-23 (1979).

[154] Choudhuri D.K. and Banerjee S., Soil factors of soil oribatid mites under conditions of West Bengal, the University of Burdwan Publication, pp. 1-88 (1977).

[155] Clapperton M.J., Kanashiro D.K. and Behan-Pelletier V.M., Changes in abundance and diversity of microarthropods associated with Fescue Prairie grazing regimes, Pedobiologia 46, 469-511 (2002).

[156] Wallwork J.A., Acari, In: Soil Biology (Eds. Burges, N.A. and Raw, F.), Academic Press. London and New York, pp. 363-395 (1967).

[157] Petersen H. and Luxton M., A comparative analysis of soil fauna populations and their role in decomposition, Oikos 39, 287-388 (1982).

[158] Luxton M., Studies on the invertebrate fauna of New Zealand peat soils V. Pasture soils on Kaipaki peat, Pedobiologia 25, 135-148 (1983).

[159] Janssens F., Checklist of Collembola of the World, http://www.Collembola.org (accessed on 31.07.2016).

[160] Mandal G.P., Suman K.K., Studies on diversity and distribution of soil micro-arthropods fauna with special reference to Collembola in Sajnekhali Wild Life Sanctuary, South 24 Pgs, West Bengal, Rec. zool. Surv. India , 114(Part-4) , 623-636 (2014).

[161] Handschin E., Considérations sur la position systématique des Collemboles, Mém. Soc. R. Ent. Belg., Tome Vingt-Septième, Volume Jublaire, pp. 40-53 (1955).

[162] Mandal G.P. and Hazra A.K., The diversity of Collembola (Hexapoda) from east and north East India with some notes on their ecology, Rec. Zool. Surv. Ind. Occas. Paper. No. 298, pp. 1-206 (2009).

[163] Lal V.B., Sinha A.K., Dezi S.L. and Lal D., Population dynamics of Collembola and Acari in wetlands and croplands in Indo-Gangetic plains of north Bihar, The BioScan 6(4), 685-689 (2011).

[164] Mandal G.P., Suman K.K. and Hazra A.K., Studies on diversity and distribution of Collembola in the forest Ecosystem at Bibhuti Bhushan Wild life Sanctuary, Parmadan, North 24pgs District, West Bengal, Rec. zool. Surv. India, 111 (4), 41-63 (2011).

[165] Singh R. and Kumar U., Ecology of Soil Arthropods in Sal and Teak Forest Ecosytem of Gorakhpur Range in Northeastern Uttar Pradesh, India. LAP Lambert Academic Publ. GmbH \& Co. KG, Germany, pp. 240 (2012).

[166] Vannier G., Modes d'exploitation et partage des ressources alimentaires dans le système saprophage par les microarthropodes du sol, Bull. Ecol. 16(1), 19-34 (1985).

[167] Lussenhop J., Mechanisms of microarthropod-microbial interactions in soil, Adv. Ecol. Res. 23, 1-33 (1992).

[168] Lavelle P., Diversity of soil fauna and ecosystem function, Biol. Internat. 33, 3-16 (1996). 
[169] Reddy V.S., Reddy M.V., Lec K.K. and Rao K.P.C., Response of some soil meso and macrofaunal populations to soil management during crop and fallow period on a semi-arid tropical alfisol (India), Eur. J. Soil Biol. 32 (3), 123-129 (1996).

[170] Mishra K.C. and Ramakrishnan P.S., Earthworm population dynamics in different jhum fallows developed after slash and burn agriculture in northeastern India, Proc. Indian Acad. Sci. (Anim. Sci.) 4, 309-318 (1988).

[171] Darlong V.T. and Alfred J.R.B., Effects of shifting cultivation (Jhum) on soil fauna with particular reference to earthworms in Northeast India. In: Advances in Management and Conservation of Soil Fauna (Eds. G.K. Veeresh, D. Rajagopal and C.A. Viraktamath), Oxford and IBH Publishing Co. Pvt. Ltd., New Delhi, pp. 299-308 (1991).

[172] Hazra A.K., Effect of deforestation on the soil macro and microarthropod fauna of West Bengal, India. In : Advances in Management and Conservation of Soil Fauna (Eds. Veeresh, G.K., Rajagopal, D. \& Viraktamath, C.A.), Oxford \& IBH Publishing Co. Pvt. Ltd., New Delhi, pp. 399-411 (1991).

[173] Menta C., Soil fauna diversity - function, soil degradation, biological indices, soil restoration. In : Environmental Sciences - Biodiversity Conservation and Utilization in a Diverse World (Ed. Lameed), G.A. DOI: 10.5772/51091 (2012).

[174] De Ruiter P.C., Neutel A.M. and Moore J.C., Soil web interactions and modeling. In: Fauna in Soil ecosystems (Ed. G. Benckiser) Marcel Dekker Inc., New York, pp. 363-386 (1997).

[175] Edwards C.A., Reichle D.E. and Crossley D.A.Jr., The role of invertebrates in turnover of organic matter and nutrients. In: Ecological Studies I: Analysis of Temperate Forest Ecosystems (Ed. Reichle, D.E) Spring Verlag, New York, 147-172 (1970).

[176] Harding D.J.L. and Stuttard R.A., Microarthropods. In: Biology of Plant Litter Decomposition (Eds. Dickinson, D.H. and Pugh, G.J.F.), Academic Press, London, pp. 489-532 (1974).

[177] Palacios-Vargas J.G., Castano-Meneses G. and Rusek J., Collembola associated with Tillandsia violacea (Bromeliaceae) in Mexican Quercus-Abies forests, Pedobiologia 46 (3-4), 395-403 (2002).

[178] Bisht B.S., Quality of edaphic factors as an index to collembolan diversity in foothills of Himalaya, Ann. Pl. Prot. Sci. 10 (2), 252-255 (2002).

[179] Dazzi C., Massa B., Veca D.M., Vacante G., Veca D. and Rubio J.L., Pedo-mesofauna activity as soil quality indicator in a forest Mollisol. Man and soil at the Third Millennium. In: Proceedings International Congress of the European Society for soil conservation (Eds. Morgan, R.P.C., Asins, S. and Andreu, V.), Valencia, Spain, 1, 871-885 (2002).

[180] Ke X., Winter K. and Filser J., Effects of soil mesofauna and farming management on decomposition of clover litter: a microcosm experiment, Soil Biol. \& Biochem. 37 (4), 731-738 (2005).

[181] Eaton R.J., Barbercheck M., Buford M. and Smith W., Effects of organic matter removal, soil compaction, and vegetation control on collembolan populations. Pedobiologia 48 (2), 121-128 (2004).

[182] Sanyal A.K., Notes on the ecology of soil mites (Acari) in two contrasting sites of Schirmacher Oasis, east Antarctica, Acarina 12(2), 151-157 (2004).

[183] Kumssa D.B., Aarde R.J. van and Wassenaar T.D., The regeneration of soil micro-arthropod assemblages in a rehabilitating coastal dune forest at Richards Bay, South Africa, African J. Ecol. 42 (4), 346-354 (2004).

[184] Reynolds B.C., Crossley D.A. Jr. and Hunter M.D., Response of soil invertebrates to forest canopy inputs along a productivity gradient, Pedobiologia 47 (2), 127-139 (2003).

[185] Curry J.P., Grassland Invertebrate: Ecology, Influence on Soil Fertility and Effects on Plant Growth, Chapman and Hall, London, pp. 437 (1994).

[186] Hubert J. and Tuckova S., The oribatid communities (Acari: Oribatida) on different stands of two meadows, Oecologia 22 (4), 443-456 (2003).

[187] Costa W.A.J.M.de, de-Costa W.A.J.M and Gunasena H.P.M., Decomposition and nutrient release from green manures of different tree species in three agroecological zones of Sri Lanka. In: Proc. Eleventh National Workshop on Multipurpose Trees, Kandy, Sri Lanka, pp. 1-34 (2000). 
[188] Roy S., Srivastava A.K. and Roy M.M., Soil arthropods inhabiting grassland and silvopastoral systems in Central India, Flora \& Fauna 4 (1), 35-39 (1998).

[189] Roy S., Shrivastava A.K. and Roy M.M., Abundance of collembolans and acarines in Hardwikia binata based silvipasture in Bundelkhand region, Indian Forester 129 (4), 531-537 (2003).

[190] Roy S., Shrivastava A.K. and Roy M.M., Abundance of collembolans and acarines in Albizia amara based silvipasture in Bundelkhand, Indian J. Forest. 28 (2), 150-155 (2005).

[191] Miyazawa K., Tsuji H., Yamagata M., Nakano H. and Nakamoto T., The effects of cropping systems and fallow managements on microarthropod populations, Pl. Prod. Sci. 5 (3), 257-265 (2002).

[192] Krebs C.J., Ecology: The Experimental Analysis of Distribution and Abundance. Harper and Row, New York, U.S.A., pp. 694 (1972).

[193] Wallwork J.A., Ecology of Soil Animals. McGraw-Hill, Publishing Company Limited, Maidenhead-Berkshire, England, pp. 283 (1970).

[194] Hole F.D., Effects of animals on soil, Geoderma 25, 75-112 (1981).

[195] Norton R.A., Aspects of the biology of soil arachnids, particularly saprophagous and mycophagous mites, Quaest. Ent. 21, 523-541 (1985).

[196] Verhoef H.A. and Brussard L., Decomposition and nitrogen mineralization in natural and agroecosystems: the contribution of soil animals, Biogeochemistry 11, 175-211 (1990).

[197] Blair J.M., Crossley Jr. D.A. and Callaham L.A., Effects of litter quality and microarthropods on N-dynamics and retention of exogenous N-15 in decomposing litter, Biol. Fert. Soils, Berlin 12, 241-252 (1992).

[198] Faber J.H., Functional classification of soil fauna: a new a approach, Oikos 62, 110-117 (1991).

[199] Rusek J., Biodiversity of Collembola and their functional role in the ecosystem, Biodiv. \& Conserv. 7, 1207-1219 (1998).

[200] Filser J. and Seatala H., Recent advances in decomposer food web ecology. In: Perspectives in Ecology (Ed. Farina, A.) Backhuys Publishers, Leiden, pp. 355-368 (1999).

[201] Lavalle P., Spain A., Blanchart E., Martin A., Martin S. and Schaefer R., The impact of soil fauna on the properties of soils in the humid tropics. In: Myths and Sciences of soils of the Tropics (Eds. R. Lal, O. Sanchez), Soil Sci. Soc. America, Washignton, pp. 157-185 (1992).

[202] Usher M.B., Aggregation responses of soil arthropods in relation to the soil environment. In: The role of Terrestrial and Aquatic Organisms in Decomposition Processes (Eds. Anderson J.M. and MacFadyen A.), Blackwell Scientific, Oxford, pp. 61-94 (1976).

[203] Wallwork J.A., Oribatids in forest ecosystems, Annu. Rev. Ent. 28, 109-130 (1983).

[204] Watanabe H., Estimation of arboreal and terrestrial arthropod densities in the forest canopy as measured by insecticide smoking. In: Canopy Arthropods (Eds. Stork, N.E., Adis, J. and Didham, R.K.), Chapman and Hall, London, pp. 401-414 (1997).

[205] Behan-Pelletier V. and Walter D.E., Biodiversity of oribatid mites (Acari: Oribatida) in tree canopies and litter. In: Invertebrates as Webmasters in Ecosystems (Eds. Coleman D.C. and Hendrix P.F.), CAB International, Wallingford, pp. 187-202 (2000).

[206] Lindquist E.E., Ainscoough B.D., Clulow F.V., Funk R.C., Marshall V.G., Nesbitt H.H.J., O'Connor B.M., Smithand I.M. and Wilkinson P.R., Acari. In: Canada and its Insect Fauna (Ed. H.V. Danks) Memoirs of Entomological Society of Canada, 108, 252-263, 267-284 (1979).

[207] Lindquist E.E., Current theories on the evolution of major groups of Acari and on their relationships with other groups of the Arachnida, with consequent implications for their classification. In: Acarology (Eds. Griffiths, D.A., Bownan, C.E.), C. Ellis Horwood, Chichester, pp. 28-62 (1984).

[208] Behan V.M., Hill S.B. and Kevan D.K.M.E., Effects of urea as fertilizer, on Acarina and other arthropods in Quebec Black spruce (Picea mariana Mill.) humus, Pedobiologia 18, 249-263 (1978).

[209] Krantz G.W., Manual of Acarology. Corvallis, Oregon, USA, pp. 335 (1978). 
[210] Brussaard L., Behan-Pelletier V.M., Bignell D.E., Brown V.K., Didden W., Folgarait P., Fragoso C., Freckman D.W., Gupta V.V.S.R., Hattori T., Hawksworth D.L., Klopatek C., Lavelle P., Malloch D.W. Rusek Soderstrom B., Tiedje J.M. and Virginia R.A., Biodiversity and ecosystem functioning in soil, Ambio 26, 563-570 (1997).

[211] Vreeken-Buijs M.J., Hassink J. and Brussaard LRelationships of soil microarthropod biomass with organic matter and pore size distribution in soils under different land use, Soil Biol. \& Biochem. 30, 97-106 (1998).

[212] Pramanik R., Sarkar K. and Joy V.C., Efficiency of detritivore soil arthropods in mobilizing nutrients from leaf litter, Trop. Ecol. 42(1), 51-58 (2001).

[213] Wallwork J.A., Observations on the behaviour of some Oribatid mites in experimentally controller temperature gradients, Proc. Zool. Soc. London 135, 619-629 (1960).

[214] Madge D.S., The behaviour of Belba geniculosa Oudms, and certain other species of oribatid mites in controlled temperature gradients, Acarologia 7, 389-406 (1965).

[215] Visser S., Role of soil invertebrates in determining the composition of soil microbial communities In: Soil (Eds. A.H. Fitler, D. Atkinson and D.J. Read), Blackwell Scientific Publishing, Boston, M.A., pp. 297-317(1985).

[216] Walter D.E., Trophic behaviour of "mycophagous" microarthropods, Ecology 68, 226-229 (1987).

[217] Moore J.C., Snider R.J. and Robertson L.S., Effects of different management practices on Collembola and Acarina in corn production systems. I. The effects of no-tillage and Atrazine, Pedobiologia 26, 143-152 (1984).

[218] Mallow D., Snider R.J. and Robertson L.S., Effects of different management practices on Collembola and Acarina in corn production systems. II. The effects of moldboard plowing and atrazine, Pedobiologia 28, 115-131 (1985).

[219] Kaneda S. and Kaneko N., Collembolans feeding on soil affect carbon and nitrogen mineralization by their influence on microbial and nematode activities, Biol. \& Fert. Soils 44(3), 435-442 (2008).

[220] Joosse E.N.G., The formations and biological significance of aggregations in the distribution of Collembola, Neth. J. Zool. 20, 299-314 (1970).

[221] Kaczmarek M., An analysis of Collembola communities in different pine forest environments, Ekol. Polska 23, 265-293 (1975).

[222] Hagvar S., Collembola in Norwegian coniferous forest soils. I Relation to plant communities and soil fertility, Pedobiologia 24, 255-296 (1982).

[223] Hagvar S. and Abrahamsen G., Collembola in Norwegian coniferous forest soils III. Relation to soil chemistry, Pedobiologia 27, 331-339 (1984).

[224] Shaw P.J.A. and Usher M.B., Edaphic Collembola of lodge pole pine Pinus contorta plantation in Cumbria, U.K., Eur. J. Soil Biol. 32, 89-97 (1996).

[225] Salmon S. and Ponge J.F., Distribution of Heteromurus nitidus (Hexapoda, Collembola) according to soil acidity: interactions with earthworms and predator pressure, Soil Biol. \& Biochem. 31, 1161-1170 (1999).

[226] Verhoef H.A. and Witteveen J., Water balance in Collembola and its relation to habitat selections, cuticular water loss and water uptake, J. Ins. Physiol. 26, 201-208 (1980).

[227] Verhoef H.A. and Van Selm A.J., Distribution and population dynamics of Collembola in relation to soil moisture, Holarc. Ecol. 6, 387-394 (1983).

[228] Hopkin S.P., Biology of the Springtails (Insecta: Collembola), Oxford Univ. Press Oxford, New York, Tokyo, pp. 330 (1997).

[229] Ferguson S.H. and Joly D.O., Dynamics of springtail and mite populations: the role of density dependence, predation, and weather, Ecol. Ent. 27 (5), 565-573 (2002).

[230] Hasegawa M., The response of collembolan Community to the amount and composition of organic matter of a forest floor, Pedobiologia, 46, 353-364 (2002).

[231] Christiansen K., Bionomics of Collembola, Annu. Rev. Ent. 9, 149-179 (1964).

[232] Ponge J.F., Biocenoses of Collembola in Atlantic temperate grass-woodland ecosystems, Pedobiologia 37, 223-244 (1993). 
[233] Hagvar S., Reactions to soil acidification in microarthropods: is competiton a key factor? Biol. \& Fert. Soils 9, 178-181 (1990).

[234] Loranger G., Bandyopadhyaya L., Razaka B. and Ponge J.F., Does soil acidity explain altitudinal sequence in Collembolan communities? Soil Biol. \& Biochem. 33, 381-393 (2001).

[235] Ponge J.F., Acidophilic Collembola: living fossils. Contributions from the Biological laboratory, Kyoto University 29, pp. 65-74 (2000).

[236] Petersen H., Population dynamics and metabolic characterization of Collembola species in a beech forest ecosystem. In: Soil Biology as Related to Land Use Practices (Ed. Dindal D.L.), Washington D.C., pp. 806-833 (1980).

[237] Hagvar S., Collembola in Norwegian coniferous forest soil II. Vertical distribution, Pedobiologia 25, 383-401(1983).

[238] Wood T.G., Acari and Collembola of moorland soil form Yorkshire England I. Description of the mites and their population, Oikos 18, 102-117 (1967).

[239] Kevan D.K.McE., Soil Animals, Philosophical Library, New York, pp. 23 (1982).

[240] Alicata P., Arcidiacono R., Caruso D. and Marcellino I., Distribution et fluctuations saisonnieres des populations de quelques especes d' oribates (Acariens) du sol d'un bois de chenes verts de I' Etna, Rev. Ecol. Biol. Sol. 10, 535-557 (1973).

[241] Hassall M., Parkinson D. and Visser S., Effects of the collembolan Onychiurus subtenuis on decomposition of Populus tremuloides leaf litter, Pedobiologia 29, 219-225 (1986).

[242] Mukharji S.P. and Singh J., Seasonal variation in the densities of a soil arthropod population in a rose garden at Varanasi (India), Pedobiologia 105, 442-446 (1970).

[243] Banerjee S., Qualitative composition and seasonal fluctuation of Oribatei (Acarina) in Burdwan soil, West Bengal (India), Acta Arachnol. 25(2), 68-72 (1974).

[244] Banerjee S., Oribatid mites and organic carbon content of soil, Acta Arachnol. 26(1), 47-50 (1974).

[245] Banerjee S., Microarthropod and nitrate content of soil, Bull. Indian Soc. Soil Sci. 11, 104-107 (1976).

[246] Sharon R., Degani G. and Warburg M., Comparing the soil macro-fauna in two oak-wood forest: does community structure differ under similar ambient conditions? Pedobiologia 45(4), 355-366 (2001).

[247] Singh J., Borah I.P. and Boruah A., Soil characteristics under three different plant communities of North-East India, Indian Forester 121(12), 1130-1133 (1995).

[248] Giller P.S., The diversity of soil communities, the "poor man's tropical rainforest", Biodiv. \& Conserv. 5, 135-168 (1996).

[249] Loots G.C. and Ryke P.A.J., The ratio Oribatei Trombidiformes with reference to organic matter content in soils, Pedobiologia 7, 121-124 (1967).

[250] Huhta V. and Hanninen S.M., Effects of temperature and moisture fluctuations on an experimental soil microarthropod community, Pedobiologia 45, 279-286 (2001).

[251] Geiger R., The Climate Near the Ground, Harvard Univ. Press, Cambridge, Mass, USA, pp. 518 (1959).

[252] Bhattacharya T. and Raychaudhuri D.N., Monthly variation in the density of soil microarthropods in relation to some climatic and edaphic factors, Entomon 4, 313-318 (1979).

[253] Anderson J.M., Inter-intra habitat relationships between woodland Cryptostigmata species diversity and the diversity of soil and litter microhabitats, Oecologia 32, 341-348 (1978).

[254] Usher M.B., Seasonal and vertical distribution of a population of soil arthropods: Mesostigmata, Pedobiologia 11, 27-39 (1971).

[255] Mitchell M.J., Vertical and horizontal distributions of oribatid mites (Acari: Cryptostigmata) in an aspen woodland soil, Ecology 69(3), 516-525 (1978).

[256] Anderson J.M., Succession, diversity and tropic relationships of some soil animals in decomposing leaf litter, J. Anim. Ecol. 44, 475-495 (1975).

[257] Darlong V.T., Ecological Studies of Soil Arthropods in Forest and Jhum Systems of Laitkor, Meghalaya. Unpublished Ph.D. Thesis, NEHU, Shillong, India, pp. 445 (1984). 
[258] Pankhurst C.E., Doube B.M. and Gupta V.V.S.R., Biological Indicators of Soil Health. CAB International, UK, pp. 451 (1997).

[259] Behan-Pelletier V. and Newton G., Linking soil biodiversity and ecosystem function-the taxonomic dilemma, Bioscience 49, 149-153 (1999).

[260] Wall D., Biodiversity and ecosystem functioning, Biol. Sci. 49, 107-108 (1999).

[261] Reddy M.V. and Venkataiah BEffect of tree plantation on seasonal community structure of soil microarthropods in a tropical semi-arid savanna, Trop. Ecol. 31, 96-105 (1990).

[262] Narula A., Vats L.K. and Handa S., Collembola and mites of deciduous forest stand, Indian J. Forest. 21, 147-149 (1998).

[263] Montanarella L., The importance of soil biodiversity and bio-indication within the EU thematic strategy for soil protection, Fresen. Env. Bull. 17, 1102-1106 (2008).

[264] Fox C., MacDonald K., Jarvis I., Walker B. and Pettapiece W., Protocols for a soil ecosystem approach for characterizing soil biodiversity. In: A Workshop Report on Terrestrial Arthropod Sampling Protocols for Graminoid Ecosystems (Ed. A.T. Finnamore) Available http://eqbdqe.cciw.ca/eman/reports/publications/sage/sage9.htm (1996).

[265] Khalil M.A., Changes in soil oribatid communities associated with conversion from conventional to organic agriculture, Exp. \& Appl. Acarol. 68(2), 83-196 (2016).

[266] Anderson J.M., Why should we care about soil fauna? Pesq. Agropec. Bras. 44(8), 835-842 (2009).

\section{AUTHORS' BIOGRAPHY}

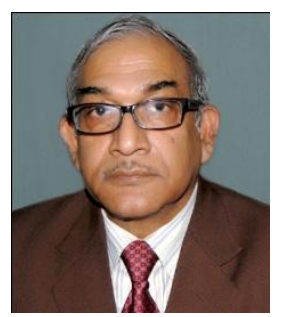

Dr. Rajendra Singh, is Professor \& Head of the Department of Zoology, Former Head of Department of Biotechnology, D.D.U. Gorakhpur University, Gorakhpur and has 38 years of experience in the fields of bioecology and biosystematics of aphids, their parasitoids and predators, spiders, and soil arthropods and published about 200 research articles of international repute, authored 6 text/reference books, supervised one D.Sc. and $26 \mathrm{Ph}$. D. students, and completed 12 research projects. $\mathrm{He}$ is fellow/life member of several scientific organizations/societies, Chief Editor of Journal of Aphidology and is on the editorial/reviewer panel of several International Journals. Prof. Singh also served in the university as Pro-Vice Chancellor.

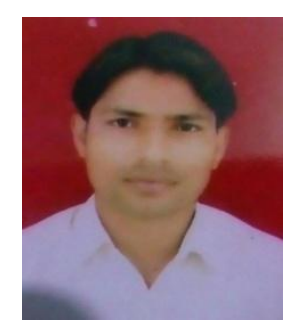

Umesh Kumar, has completed his Ph.D. on ecology of soil arthropods in sal and teak forest ecosytem of Gorakhpur range in northeastern Uttar Pradesh, India. He has skill in statistical analysis, diversity analysis etc. During his research period he had presented papers in several national and international seminars and symposia. Presently he is serving as Assistant Professor in S.R. Degree College, Banspar, Gorakhpur. 